\title{
Morphometric characteristics of crayfish, Cherax gherardiae, from Maybrat, West Papua, Indonesia
}

\author{
Yulianus Sedik, Dominggus Rumahlatu, Bambang Irawan, Agoes Soegianto
}

Received - 05 February 2018/Accepted - 14 November 2018. Published online: 31 December 2018; Inland Fisheries Institute in Olsztyn, Poland Citation: Sedik Y., Rumahlatu D., Irawan B., Soegianto A. 2018 - Morphometric characteristics of crayfish, Cherax gherardiae, from Maybrat, West Papua, Indonesia - Fish. Aquat. Life 26: 223-230.

\begin{abstract}
The objectives of this study were to determine the length-weight relationships (LWRs), chelae length (ChL)-width (ChW) relationships, carapace length (CL)-width (CW) relationships, sexual dimorphism, and condition factor $(\mathrm{K})$ of Cherax gherardiae from Maybrat, West Papua Indonesia. The sex ratio of $C$. gherardiae was found to be 1.04:1. The LWRs for males, females, and all individuals were $\mathrm{W}=0.225 \mathrm{~L}^{1.96}, \mathrm{~W}=$ $0.181 \mathrm{~L}^{2.02}$, and $\mathrm{W}=0.187 \mathrm{~L}^{2.03}$, respectively. Males and females exhibited negative allometric growth $(b<3)$. There was no significant difference in lengths between males and females; however, the weight of males was greater than that of females. The K values for males, females, and all individuals were 3.17, 3.09, and 3.13, respectively. The ChL of the crayfish ranged from 1.0 to $7.5 \mathrm{~cm}$, and the $\mathrm{ChW}$ ranged from 0.4 to $2.5 \mathrm{~cm}$. The CL of crayfish ranged from 1.6 to $6.0 \mathrm{~cm}$, and the CW ranged from 0.6 to $4.1 \mathrm{~cm}$. Males had longer chelae and carapaces than did females. There was no significant difference in chelae width or carapace width between males and females. The ChL-ChW relationships for males, females, and all individuals were $\mathrm{ChW}=0.312 \mathrm{ChL}+0.260$, $\mathrm{ChW}=$
\end{abstract}

Y. Sedik, A. Soegianto [ $\Xi^{-}$, Study Program of Environmental Science and Technology, Faculty of Sciences and Technology,

Universitas Airlangga, Surabaya, Indonesia

e-mail: agoes_soegianto@unair.ac.id

D. Rumahlatu

Study Program of Biology Education, Faculty of Teacher Education,

Universitas Pattimura, Ambon, Indonesia

B. Irawan, A. Soegianto

Department of Biology, Faculty of Sciences and Technology,

Universitas Airlangga, Surabaya, Indonesia
$0.397 \mathrm{ChL}-0.050$, and $\mathrm{ChW}=0.345 \mathrm{ChL}+0.119$, respectively. The CL-CW relationships for males, females, and all individuals were $\mathrm{CW}=0.750 \mathrm{CL}-0.955, \mathrm{CW}=0.526 \mathrm{CL}-0.178$, and $\mathrm{CW}=0.635 \mathrm{CL}-0.543$, respectively.

Keywords: Cherax, crayfish, morphometry, Papua

\section{Introduction}

Freshwater crayfishes of the family Parastacidae are typical fauna representatives of Papua, Indonesia. Holthuis (1982) reported that all crayfish in Papua, Indonesia and New Guinea belong to this family and the genus Cherax. Although the crayfish of Papua, Indonesia and New Guinea have been studied extensively (Holthuis 1949, 1956, 1958, 1982, 1986, 1996, Lukhaup and Pekny 2006, 2008, Lukhaup and Herbert 2008, Lukhaup 2015, Lukhaup et al. 2015, 2017, Patoka et al. 2015a, 2015b), previous research focused on the taxonomy and morphological description of the new species of Cherax. Very few studies have been conducted on the basic morphometric characters of these crayfish including Cherax gherardiae. To our knowledge, only Weya et al. (2017) have studied the length-weight relationship and condition factor of crayfish in Papua Indonesia, but they excluded $C$. gherardiae. 
C. gherardiae is endemic to the Ayamaro Lakes and the Ayamaro River and its surrounding area in Maybrat Regency, West Papua, Indonesia (Lukhaup and Pekny 2008). C. gherardiae from West Papua are captured in the field and exported by Indonesian wholesalers to the European, North American, and Japanese pet markets (Lukhaup and Herbert 2008, Patoka et al. 2015a). To date, the Cherax from West Papua that are traded have yet to be described scientifically, and their quantities in which they are captured are not registered by any relevant authorities (Patoka et al. 2015a); therefore, the possible decline of the abundance of these species remains unknown.

Measuring individual body length and weight is a basic morphometric procedure in the scientific study of the species. The length-weight relationship (LWR) is a very important parameter for the characteristics of crayfish populations, and it is used to estimate growth rates, to evaluate size at sexual maturity, to calculate weights at certain lengths (and vice versa), and to calculate condition factor to permit comparisons among populations from different regions (Lindqvist and Lahti 1986, Milosevic and Talevski 2016). The condition factor can be used to assess the degree of well-being of organisms in their habitats (Mac Gregoer 1959). When the condition factor value is higher than one, this means that the animal has attained a better condition. The condition factors of aquatic organisms can be affected by a number of elements such as stress, food availability, season, and habitat water quality (Lindqvist and Lahti 1986, Milosevic and Talevski 2016). Furthermore, relations among body parts are used to segregate males from females and to compare crayfish populations from different regions (Deniz et al. 2010). An LWR study of a species can provide important insights into its ecology (Froese 2006). Pauly (1993) states that LWR provides valuable information on the habitat where a species lives. Therefore, understanding the relationship between length and weight might have important implications for the management of crayfish in their natural habitats.

In crustaceans, chelae length and width are important factors in aggressive behavior, and they play a significant role in determining competitive outcomes. Crayfish species compete for limited resources such as food, shelter, and space (Nakata and Goshima 2003, Mazlum and Eversole 2005); thus, morphometric relationships between chelae length and width are very important subjects to study. The objective of this study was to determine the L-W relationships, ChL-ChW relationships, CL-CW relationships, sexual dimorphism, and condition factors of $C$. gherardiae from Maybrat, West Papua, Indonesia.

\section{Materials and methods}

Male and female $C$. gherardiae were caught in creeks located to the northeast of Ayamaro Lake, Maybrat Regency West Papua (lat. 16’6.06" - 17'22.62"S; $\left.132^{\circ} 29^{\prime} 30.48^{\prime \prime}-132^{\circ} 29^{\prime} 32.94 " E\right)$ Indonesia (Fig. 1). Specimens were collected between November 2016 and January 2017 in creeks measuring 4-8 $\mathrm{m}$ in

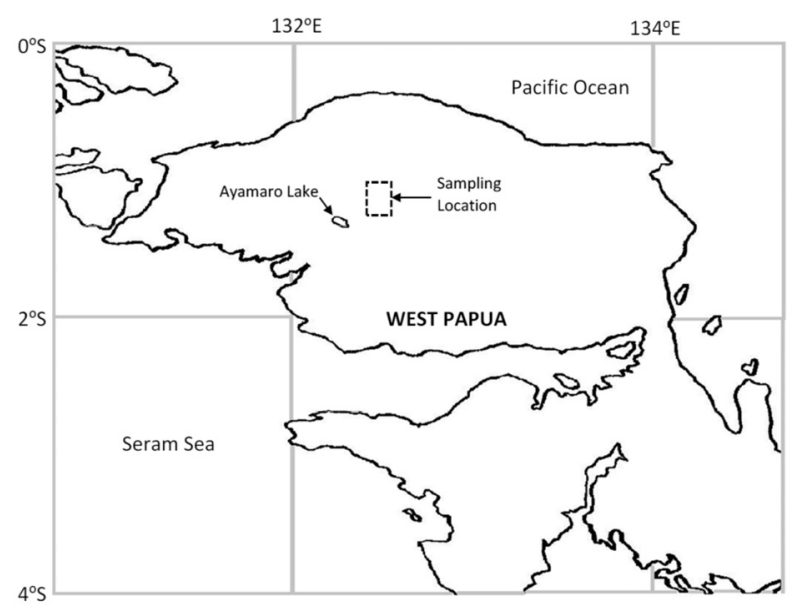

Figure 1. Sampling location of Cherax gherardiae in Maybrat, West Papua, Indonesia.

width and 0.3-0.7 $\mathrm{m}$ in depth. The beds of the creeks consisted of stones, rocks, and pebbles and offered plenty of shelter for crayfish. The river banks were overgrown with dense vegetation.

The crayfish were collected with the assistance of the local people using cast nets, noken (a knotted net or woven bag handmade from wood fiber or leaves by communities in Papua Indonesia), and by hand to pick and dislodge them from their burrows. The 


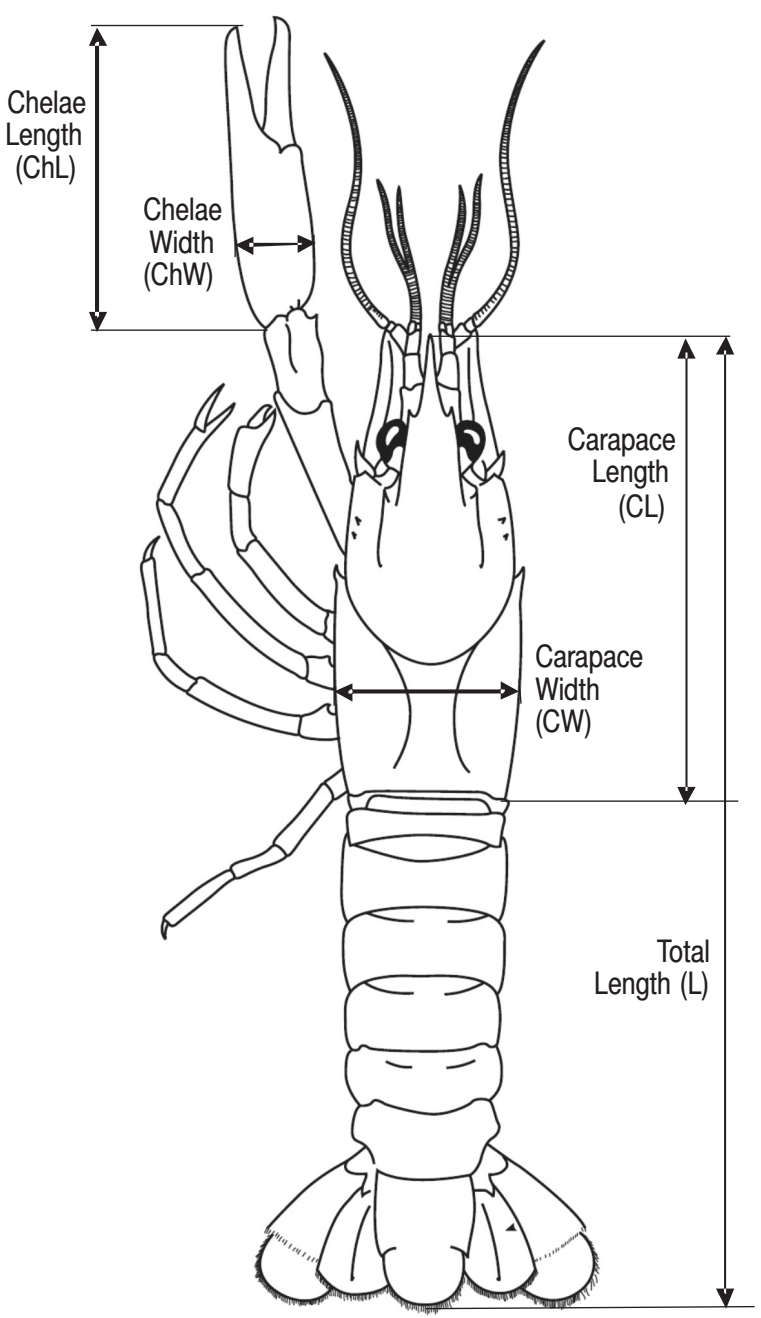

Figure 2. Morphometric measurements taken for Cherax gherardiae individuals. $\mathrm{L}=$ total length, $\mathrm{CL}=$ carapace length, $\mathrm{CW}=$ carapace width, $\mathrm{ChL}=$ chelae length, $\mathrm{ChW}=$ chelae width . Line art modified from Loughman and Simon (2011).

animals were placed in clean plastic buckets and transported to the laboratory for analysis. The morphological identification followed Patoka et al. (2015a, 2015b). The crayfish were placed on filter paper for several minutes to remove excess water, then weighed to the nearest $0.01 \mathrm{~g}$. Total length (L), carapace length $(\mathrm{CL})$, carapace width $(\mathrm{CW})$, chelae length (ChL), and chelae width (ChW) were measured to the nearest $0.01 \mathrm{~cm}$ (Fig. 2). Only individuals with complete chelipeds, a full complement of walking legs, and no visible body deformations were used to determine the length-weight relationships. Individuals were segregated by sex, and ovigerous females were noted, but they were not included in the morphometric analysis.

The chi-squared $\left(\chi^{2}\right)$ test was used to evaluate differences in the sex ratio for the entire sample. The length-weight relationships (LWRs) were calculated using the equation $\mathrm{W}=\mathrm{aL}^{\mathrm{b}}$, where $\mathrm{W}$ is the total weight of the crayfish $(\mathrm{g}), \mathrm{L}$ is the total length $(\mathrm{cm})$, $a$ is the intercept, and b is the slope (Ricker 1975). The parameters $\mathrm{a}$ and $\mathrm{b}$ were estimated by the linear regression of the transformed equation: $\log \mathrm{W}=\log$ $a+b \log L$. The determination coefficient $\left(\mathrm{r}^{2}\right)$ was used as an indicator of the quality of the linear regression. Slope (b) is used to describe the growth type of the crayfish: for $b=3$ growth is isometric, for $b<3$ is negatively allometric, and for $\mathrm{b}>3$ is positively allometric (Zar 1999). The relationships between ChL-ChW and CL-CW for each sex were also determined using regression analysis. Differences in L, W, ChL, ChW, CL, and CW values between males and females were tested using Student's t-test (Zar 1999). Analysis of covariance (ANCOVA) was used to compare the L-W, ChL-ChW, and CL-CW regressions between males and females for significant differences. Before being subjected to a parametric statistical test, the normality of the measurement variables was verified with the Kolmogorov-Smirnoff normality test. If the data did not fit a normal distribution, we applied log transformations to make the data normally distributed.

Fulton's condition factor $(\mathrm{K})$ was calculated using the equation $\mathrm{K}=100 \times\left(\mathrm{W} \times \mathrm{L}^{-3}\right)($ Ricker 1975), where $\mathrm{W}$ is the total weight of the crayfish $(\mathrm{g})$ and $\mathrm{L}$ is the total length $(\mathrm{cm})$. K values of crayfish were determined separately according to the total length of female and male individuals. Differences between the $\mathrm{K}$ values of females and males was tested using Student's t-test (Zar 1999).

During crayfish collection, the water quality parameters of the habitat were measured, as follows: temperature with glass mercury thermometers $\left({ }^{\circ} \mathrm{C}\right)$; pH with a pH meter (Lutron PH 207 HA); dissolved oxygen (DO) with DO meter (Hach Sension 6); turbidity with portable turbidity meter (Hanna HI 98703). The values of temperature, $\mathrm{pH}$, dissolved 
oxygen, and turbidity were $26.0-26.5^{\circ} \mathrm{C}, 7.40-7.62$, 7.7-8.2 $\mathrm{mg} \mathrm{L}^{-1}$, and 1.77-2.64 NTU, respectively.

\section{Results}

\section{Sex ratio, length-weight relationship, and condition factor}

The characteristics of the crayfish samples are presented in Table 1 . The sex ratio was found to be 1.04:1 (53 females/51 males). This value was not significantly different from the theoretical $1: 1$ values $\left(\chi^{2}=0.2, \mathrm{P}>0.05\right)$. In total, 75 specimens (male $=$ 38 , female $=37$ ) were examined for LWRs (Table 2).

Table 1

Crayfish sample characteristics

\begin{tabular}{llll}
\hline \hline Category & $\mathrm{N}$ & $\begin{array}{l}\text { Number of crayfish with } \\
\text { incomplete chelipeds }\end{array}$ & $\begin{array}{l}\text { Ovigerous } \\
\text { female }\end{array}$ \\
\hline \hline Male & 51 & 13 & - \\
Female & 53 & 11 & 5 \\
Total & 104 & 24 & 5 \\
\hline \hline
\end{tabular}

Note: $\mathrm{N}=$ number of crayfish
The LWRs for males, females, and all individuals were described as follows: $\mathrm{W}=0.224 \mathrm{~L}^{1.96}, \mathrm{~W}=$ $0.181 \mathrm{~L}^{2.02}$, and $\mathrm{W}=0.187 \mathrm{~L}^{2.03}$, respectively. The males, females, and all individuals exhibited negative allometric growth $(b<3)$. The length-weight regression differed significantly between males and females (ANCOVA; length $\mathrm{P}=0.000$; sex $\mathrm{P}=0.011$; corrected model $\left.\mathrm{P}=0.000 ; \mathrm{r}^{2}=0.893\right)$. The condition factor $(\mathrm{K})$ of males, females, and all individuals ranged from 1.62 to $6.30,1.52$ to 6.60 , and 1.52 to 6.60 , respectively (Table 2 ). There were no significant differences in $\mathrm{K}$ between males and females $(\mathrm{P}>0.05)$.

\section{ChL-ChW and CL-CW relationships}

The regressions for the ChL-ChW relationship for males, females, and all individuals were $\mathrm{ChW}=$ $0.312 \mathrm{ChL}+0.260$, ChW $=0.397 \mathrm{ChL}-0.050$, and $\mathrm{ChW}=0.345 \mathrm{ChL}+0.119$, respectively (Table 3$)$. The ChL-ChW regressions did not differ significantly between males and females (ANCOVA; chelae length $\mathrm{P}=0.000$; $\operatorname{sex} \mathrm{P}=0.346$; corrected model $\mathrm{P}=$ $\left.0.000 ; r^{2}=0.749\right)$.

Table 2

Length-weight relationship analysis and condition factor $(\mathrm{K})$ of crayfish from Maybrat West Papua Indonesia

\begin{tabular}{|c|c|c|c|c|c|c|c|c|c|c|c|c|c|}
\hline \multirow[b]{2}{*}{ Category } & \multirow[b]{2}{*}{$\mathrm{N}$} & \multicolumn{3}{|c|}{ Total length (cm) } & \multicolumn{3}{|l|}{ Weight (g) } & \multicolumn{3}{|c|}{$\begin{array}{l}\text { Parameter of L-W } \\
\text { relationship }\end{array}$} & \multirow{2}{*}{$\begin{array}{l}\text { Growth } \\
\text { type }\end{array}$} & \multicolumn{2}{|l|}{$\mathrm{K}$} \\
\hline & & Mean \pm SD & Min & Max & Mean \pm SD & Min & Max & $\mathrm{a}$ & $\mathrm{b}$ & $r^{2}$ & & Range & Mean \pm SD \\
\hline Male & 38 & $7.07 \pm 1.85^{\mathrm{a}}$ & 4.2 & 12.5 & $11.21 \pm 7.06^{b}$ & 4.11 & 39.84 & 0.225 & 1.96 & 0.874 & $-A$ & $1.62-6.30$ & $3.17 \pm 1.04^{\mathrm{a}}$ \\
\hline Female & 37 & $6.44 \pm 1.57^{\mathrm{a}}$ & 3.6 & 11.1 & $8.33 \pm 4.95^{\mathrm{a}}$ & 3.08 & 20.74 & 0.181 & 2.02 & 0.897 & $-A$ & $1.52-6.60$ & $3.09 \pm 0.91^{\mathrm{a}}$ \\
\hline Total & 75 & $6.76 \pm 1.73$ & 3.6 & 12.5 & $9.79 \pm 6.24$ & 3.08 & 39.84 & 0.187 & 2.03 & 0.883 & $-\mathrm{A}$ & $1.52-6.60$ & $3.13 \pm 0.97$ \\
\hline
\end{tabular}

Note: $\mathrm{N}=$ number of crayfish, $\mathrm{SD}=$ standard of deviation, $\mathrm{K}=$ condition factor, $\mathrm{a}=$ intercept, $\mathrm{b}=$ slope, $\mathrm{r}^{2}=$ determination coefficient, $-\mathrm{A}=$ negative allometric growth, different letters indicate significant differences $(\mathrm{P}<0.05, \mathrm{a}<\mathrm{b})$

Table 3

Chelae length, chelae width, and chelae length-width regression of crayfish from Maybrat West Papua Indonesia

\begin{tabular}{|c|c|c|c|c|c|c|c|c|c|c|}
\hline \multirow[b]{2}{*}{ Category } & \multirow[b]{2}{*}{$\mathrm{N}$} & \multicolumn{3}{|c|}{ Chelae length $(\mathrm{cm})$} & \multicolumn{3}{|c|}{ Chelae width $(\mathrm{cm})$} & \multicolumn{3}{|c|}{ Parameter of ChL-ChW regression } \\
\hline & & Mean \pm SD & Min & Max & Mean \pm SD & Min & Max & a & $\mathrm{b}$ & $\mathrm{r}^{2}$ \\
\hline Male & 51 & $3.53 \pm 1.40^{\mathrm{b}}$ & 1.4 & 7.5 & $1.36 \pm 0.47^{\mathrm{a}}$ & 0.6 & 2.5 & 0.260 & 0.312 & 0.853 \\
\hline Female & 48 & $2.72 \pm 0.92^{\mathrm{a}}$ & 1.0 & 4.6 & $1.03 \pm 0.47^{\mathrm{a}}$ & 0.4 & 2.3 & -0.050 & 0.397 & 0.597 \\
\hline Total & 99 & $3.13 \pm 1.25$ & 1.0 & 7.5 & $1.20 \pm 0.50$ & 0.4 & 2.5 & 0.119 & 0.345 & 0.746 \\
\hline
\end{tabular}

Note: $\mathrm{N}=$ number of crayfish, $\mathrm{SD}=$ standard of deviation, $\mathrm{a}=$ intercept, $\mathrm{b}=$ slope, $\mathrm{r}^{2}=$ determination coefficient, different letters indicate significant differences $(\mathrm{P}<0.05, \mathrm{a}<\mathrm{b})$ 
The regressions for the CL-CW relationship for males, females, and all individuals were $\mathrm{CW}=$ $0.750 \mathrm{CL}-0.955, \mathrm{CW}=0.526 \mathrm{CL}-0.178$, and $\mathrm{CW}=$ $0.635 \mathrm{CL}-0.543$, respectively (Table 4). There were no significant differences in the CL-CW regressions between males and females (ANCOVA; carapace length $\mathrm{P}=0.000$; sex $\mathrm{P}=0.878$; corrected model $\mathrm{P}=$ $\left.0.000 ; r^{2}=0.864\right)$.

\section{Sexual dimorphism}

The L of the 75 crayfish ranged from 3.6 to $12.5 \mathrm{~cm}$, and the $\mathrm{W}$ ranged from 3.08 to $39.84 \mathrm{~g}$ (Table 1 ). There was no significant difference in $\mathrm{L}$ between males and females $(\mathrm{P}>0.05)$; however, the $\mathrm{W}$ of males was greater than that of females $(\mathrm{P}<0.05)$. The ChL of the 99 crayfish ranged from 1.0 to $7.5 \mathrm{~cm}$, and the ChW ranged from 0.4 to $2.5 \mathrm{~cm}$ (Table 3). The CL of crayfish ranged from 1.6 to $6.0 \mathrm{~cm}$, and the $\mathrm{CW}$ ranged from 0.6 to $4.1 \mathrm{~cm}$ (Table 4). Males had longer chelae and carapaces that did females $(\mathrm{P}<0.05)$. There were no significant differences in either chelae and carapace widths between the males and females $(\mathrm{P}>0.05)$. research conducted on crayfish species such as Orconectes limosus (Alekhnovich et al. 1999), Austropotamobius pallipes (Fenouil and Chaix 1985, Gherardi et al. 1997, Grandjean et al. 2000), Astacus leptodactylus (Deniz et al. 2010), and Pacifastacus leniusculus (Kirjavainen and Westman 1999, Capurro et al. 2007). Most authors found higher catches of males than females, and they suggest that this could result from the crayfish males being more active than females, and also because females are inactive during and after the breeding season; therefore, collection tends to be biased toward males (Gherardi et al. 1997, Kirjavainen and Westman 1999, Grandjean et al. 2000, Capurro et al. 2007).

In our studies, the length-weight relationships of C. gherardiae males, females, and all individuals showed negative allometric growth $(b<3.0)$. Similar results were reported for Procambarus alleni (Hobbs et al. 1989) and C. snowden (Weya et al. 2017). Other results showed positive allometric growth (b>3.0) for P. zonangulus (Romaire et al. 1977), C. quadricarinatus, C. destructor (Austin 1995), $P$. alleni (Acosta and Perry 2000), P. acutus acutus (Mazlum et al. 2007), and A. leptodactylus (Deniz et

Table 4

Carapace length, carapace width, and carapace length-width regression of crayfish from Maybrat West Papua Indonesia

\begin{tabular}{|c|c|c|c|c|c|c|c|c|c|c|}
\hline \multirow[b]{2}{*}{ Category } & \multirow[b]{2}{*}{$\mathrm{N}$} & \multicolumn{3}{|c|}{ Carapace length $(\mathrm{cm})$} & \multicolumn{3}{|c|}{ Carapace width $(\mathrm{cm})$} & \multicolumn{3}{|c|}{ Parameter of CL-CW regression } \\
\hline & & Mean \pm SD & Min & Max & Mean \pm SD & Min & Max & a & $\mathrm{b}$ & $r^{2}$ \\
\hline Male & 51 & $3.54 \pm 0.86^{\mathrm{b}}$ & 1.6 & 6.0 & $1.70 \pm 0.69^{\mathrm{a}}$ & 0.6 & 4.1 & -0.995 & 0.750 & 0.894 \\
\hline Female & 48 & $3.30 \pm 0.89^{\mathrm{a}}$ & 2.0 & 5.2 & $1.56 \pm 0.50^{\mathrm{a}}$ & 0.6 & 2.6 & -0.178 & 0.526 & 0.880 \\
\hline Total & 99 & $3.42 \pm 0.88$ & 1.6 & 6.0 & $1.63 \pm 0.60$ & 0.6 & 4.1 & -0.543 & 0.635 & 0.864 \\
\hline
\end{tabular}

Note: $\mathrm{N}=$ number of crayfish, $\mathrm{SD}=$ standard of deviation, $\mathrm{a}=$ intercept, $\mathrm{b}=$ slope, $\mathrm{r}^{2}=$ determination coefficient, different letters indicate significant differences $(\mathrm{P}<0.05, \mathrm{a}<\mathrm{b})$

\section{Discussion}

The sex ratios in most natural crayfish populations are close to 1:1 (Abrahamsson 1971, Kirjavainen and Westman 1999). Our study found that the sex ration of the crayfish $C$. gherardiae form Maybrat West Papua was: 1.04:1 (females/males), which was not significantly different from the expected value of $1: 1$. Our results differ from the findings of other al. 2010), and isometric growth $(b=3.0)$ for $A$. leptodactylus (Aydin et al. 2015) and P. fallax (Hobbs et al. 1989). These differences could be the reflection of a number of factors, including population density, food abundance, water level fluctuations, water temperature, water quality, and photoperiod (Huner and Romaire 1979, Chien and Avault 1983, Acosta and Perry 2000). Lindqvist and Lahti (1983) suggest that the variation of 
length-weight relationships among crayfish species is also affected by sex, sexual stage, and ecological conditions.

Sexual dimorphism is common in freshwater crayfish species (Lindqvist and Lahti 1983, Holdich 2001, Mazlum et al. 2007, Wang et al. 2011). Our study determined that the mean carapace length of the males was longer than that of the females. Since there was no difference in body lengths between male and female $C$. gherardiae, at equal-size the females of this species had longer abdomens than males. A longer abdomen in females could be because they carry eggs under the abdomen (Wang et al. 2011). Variation in abdomen length is commonly found in freshwater crayfish and is always related to sex, sexual maturity, and size (Wetzel 2002, Simon and Stewart 2014).

The most obvious sexual dimorphism in crayfish is seen in the disproportionately rapid growth of chelae in males compared to that of females. Differences between male and female chelae lengths are well documented in crayfish (Deniz et al. 2010, Wang et al. 2011, Simon and Stewart 2014). In the present study, the chelae of male $C$. gherardiae were longer than those of females. With longer chelae, male crayfish have a distinct advantage in activities related to sexual reproduction (Stein 1976) and to competition for food, shelter, and space (Nakata and Goshima 2003, Mazlum and Eversole 2005). Chybowski (2007), in a study of the morphometric characters of the spiny-cheek crayfish (Orconectes limosus), reports that at the same body length the females had shorter cheliped lengths and narrower widths than those of the males. These same characters were also observed in signal crayfish, Pacifastacus leniusculus (Chybowski 2014).

The condition factors $(\mathrm{K})$ of male and female $C$. gherardiae were not significantly different. Their average values were 3.17 for males and 3.09 for females. To the best of our knowledge, no data exists on the condition factor of this species from other locations. Therefore, we cannot compare our data with other findings on the same species. According to Lindqvist and Lahti (1986) and Milosevic and Talevski (2016), C. gherardiae attained a better condition $(K>1)$ in this habitat. Other researchers also reported that most crayfish species demonstrated higher K values including A. torrentium (3.3) (Streissl and Hodl 2002), P. acutus (1.6) (Mazlum et al. 2007), P. clarkii (2.3) (Wang et al. 2011), O. rustucus (1.5) (Anderson and Simon 2015), O. virilis (5.8) (Simon and Stewart 2014), and A. leptodactylus (2.6) (Aydin et al. 2015). The difference of condition factors of crayfish among species and locations could be a reflection of a number of factors, including population density, sex, sexual stage, food abundance, photoperiod, water level fluctuations, and water quality (Lindqvist and Lahti 1983, Acosta and Perry 2000). Crayfish inhabiting habitats that are under no anthropogenic pressure and with a variety of suitable shelters have higher $\mathrm{K}$ values (Vorburger and Ribi 1999, Streissl and Hodl 2002, Maguire and Klobucar 2011). Similarly Weya et al. (2017) report that crayfish living in a habitat that provides a more suitable environment and a higher supply of food have higher $\mathrm{K}$ values.

\section{Conclusions}

The present study is the first report on the growth and morphometry of $C$. gherardiae from West Papua, Indonesia, especially from Maybrat Regency. This study provides baseline information on length-weight relationships, chelae length-width relationships, carapace length-width relationships, sexual dimorphism, and condition factors of crayfish that will be beneficial for further reference.

Acknowledgements. This study was supported by a grant (Riset Mandat) from Universitas Airlangga. We thank the local people who helped collect the crayfish. Author contributions. Y.S., D.R., B.I., A.S. conceived and designed the research; Y.S., and D.R., and B.I. performed the research; A.S. supervised the research; Y.S., D.R., and A.S. analyzed the data and wrote the paper. 


\section{References}

Abrahamsson S.A.A. 1971 - Density, growth and reproduction in populations of Astacus astacus and Pacifastacus leniusculus in an isolated pond - Oikos 22: 373-380.

Acosta C.A., Perry S.A. 2000 - Differential growth of crayfish Procambarus alleni in relation to hydrological conditions in marl prairie wetlands of Everglades National Park, USA - Aquat. Ecol. 34: 389-395.

Alekhnovich A.V., Ablov S.E., Kulesh V.F., Pareiko O.A. 1999 - The American spiny-cheek crayfish, Orconectes limosus in the fauna of Belarus - In: Crayfish in Europe as alien species - How to make the best of a bad situation? (Eds) F. Gherardi, D.M. Holdich, A.A. Balkema, Rotterdam, Brookfield: 237-242.

Anderson W.E., Simon T.P. 2015 - Length-weight Relationship, Body Morphometrics, and Condition Based on Sexual Stage in the Rusty Crayfish, Orconectes rusticus Girard, 1852 (Decapoda, Cambaridae) with Emphasis on Management Implications - Fish. Aquac. J. 6: 3.

Austin C.M. 1995 - Length-weight relationships of cultured species of Australian freshwater crayfish of the genus Cherax - Freshw. Crayfish 10: 410-418.

Aydin H., Harlioglu M.M., Deniz T. 2015 - An investigation on the population parameters of freshwater crayfish (Astacus leptodactylus Esch., 1823) in Lake Iznik (Bursa) - Turk. J. Zool. 39: 660-668.

Capurro M., Galli L., Mori M., Salvidio S., Arillo A. 2007 The signal crayfish, Pacifastacus leniusculus (Dana, 1852) [Crustacea: Decapoda: Astacidae], in the Brugneto Lake (Liguria, NW Italy). The beginning of the invasion of the River Po watershed? - Aquat. Invasions 2: 17-24.

Chien Y.H., Avault J.W.Jr. 1983 - Effects of flooding dates and disposals of rice straw on crayfish, Procambarus clarkii (Girard), culture in rice fields - Aquaculture 31: 339-359.

Chybowski Ł. 2007 - Morphometrics, fecundity, density, and feeding intensity of the spiny cheek crayfish Orconectes limosus (Raf.) in natural conditions - Arch. Pol. Fish. 15: 175-241.

Chybowski Ł. 2014 - Morphometric differentiation in four populations of signal crayfish, Pacifastacus leniusculus (Dana), in Poland - Arch. Pol. Fish. 22: 229-233.

Deniz (Bok) T., Harlioglu M.M., Deval M.C. 2010 - A study on the morphometric characteristics of Astacus leptodactylus inhabiting the Thrace region of Turkey Knowl. Managt. Aquatic Ecosyst. 397: 05 DOI: https://doi.org/10.1051/kmae/2010021.

Fenouil E., Chaix J.C. 1985 - Biological cycle and behavior of a population of Austropotamobius pallipes - Ecol. Mediterr. 11: 3-24.

Froese R. 2006 - Cube law, condition factor and weight-length relationships: history, meta-analysis and recommendations - J. Appl. Ichthyol. 22: 241-253.
Gherardi F., Villanelli F., Dardi P. 1997 - Behavioural ecology of the white-clawed crayfish, Austropotamobius pallipes, in a Tuscan stream: preliminary results - Freshw. Crayfish 11: 182-193.

Grandjean F., Cornuault B., Archambault S., Brandmard M., Otrebsky G. 2000 - Life history and population biology of the white-clawed crayfish, Austropotamobius pallipes, in a brook from the Poitou-Charentes Region (France) Bull. Fr. Pęche Piscicult. 356: 55-70.

Hobbs H.H.Jr., Jass, J.P., Huner J.V. 1989 - A review of global crayfish introductions with particular emphasis on two North American species (Decapoda, Cambaridae) Crustaceana 56: 229-316.

Holdich D.M. 2001 - Biology of Freshwater Crayfish - Oxford England: Wiley-Blackwell Publishing, 512 p.

Holthuis L.B. 1949 - Decapoda Macrura with a revision of the New Guinea Parastacidae. Zoological Results of the Dutch New Guinea Expedition 1939. No. 3 - Nova Guinea 5: 289-330.

Holthuis L.B. 1956 - Native fisheries of freshwater Crustacea in Netherlands New Guinea. Contributions to New Guinea Carcinology. I. - Nova Guinea 7: 123-137.

Holthuis L.B. 1958 - Freshwater Crayfish in Netherlands New Guinea Mountains - South Pacific Commission Quarterly Bulletin 8: 36-39.

Holthuis L.B. 1982 - Freshwater Crustacea Decapoda of New Guinea - In: Biogeography and ecology of New Guinea, vol. 2 (Ed.) J.L. Gressitt, Monographiae Biologicae 42: 603-619.

Holthuis L.B. 1986 - The freshwater crayfish of New Guinea Freshw. Crayfish 6: 48-58.

Holthuis L.B. 1996 - Cherax (Astaconephrops) minor new species, a parastacid from the mountains of Irian Jaya (W. New Guinea) Indonesia (Crustacea: Decapoda: Parastacidae) - Zool. Med. Leiden 70: 361-366.

Huner J.V., Romaire R.P. 1979 - Size at maturity as a means of comparing populations of Procambarus clarkii (Girard) (Crustacea, Decapoda) from different habitats Freshw. Crayfish 4: 53-64.

Kirjavainen J., Westman K. 1999 - Natural history and development of the introduced signal crayfish, Pacifastacus leniusculus, in a small, isolated Finnish lake, from 1968 to 1993 - Aquat. Living Res. 12: 387-401.

Lindqvist O.V., Lahti E. 1983 - On the sexual dimorphism and condition index in the crayfish, Astacus astacus L., in Finland - Freshw. Crayfish 5: 3-11.

Loughman Z.J., Simon T.P. 2011 - Zoogeography, taxonomy, and conservation of West Virginia's Ohio River floodplain crayfishes (Decapoda, Cambaridae) ZooKeys 74: 1-78.

Lukhaup C. 2015 - Cherax (Astaconephrops) pulcher, a new species of freshwater crayfish (Crustacea, Decapoda, Parastacidae) from the Kepala Burung (Vogelkop) 
Peninsula, Irian Jaya (West Papua), Indonesia - ZooKeys 502: 1-10.

Lukhaup C., Pekny R. 2006 - Cherax holthuisi, a new species of crayfish (Crustacea: Decapoda: Parastacidae) from the centre of the Vogelkop Peninsula in Irian Jaya (West New Guinea), Indonesia - Zool. Med. Leiden 80: 101-107.

Lukhaup C., Pekny R. 2008 - Cherax (Astaconephrops) boesemani, a new species of crayfish (Crustacea: Decapoda: Parastacidae) from the centre of the Vogelkop Peninsula in Irian Jaya (West New Guinea), Indonesia Zool. Med. Leiden 82: 331-340.

Lukhaup C., Herbert B. 2008 - Cherax peknyi sp. nov., a new species of crayfish (Crustacea: Decapoda: Parastacidae) from the Fly River Drainage, Western Province, Papua New Guinea - Mem. Queensl. Mus. 52: 213-219.

Lukhaup C., Panteleit J., Schrimpf A. 2015 - Cherax snowden, a new species of crayfish (Crustacea, Decapoda, Parastacidae) from the Kepala Burung (Vogelkop) Peninsula in Irian Jaya (West Papua), Indonesia - ZooKeys 518: 1-14.

Lukhaup C., Eprilurahman R., von Rintelen T. 2017 - Cherax warsamsonicus, a new species of crayfish from the Kepala Burung (Vogelkop) peninsula in West Papua, Indonesia (Crustacea, Decapoda, Parastacidae) ZooKeys 660: 151-167.

Mac Gregoer J.S. 1959 - Relation between fish condition and population size in the sardine (Sardinops caerulea). U.S. Fishery Wild Service - Fish. Bull. 60: 215-230.

Maguire I., Klobucar G. 2011 - Size structure, maturity size, growth and condition index of stone crayfish (Austropotamobius torrentium) in North-West Croatia Knowl. Managt. Aquatic Ecosyst. 401: 12 DOI: https://doi.org/10.1051/kmae/2011026

Mazlum Y., Eversole A.G. 2005 - Growth and survival of Procambarus acutus acutus (Girard, 1852) and P. clarkii (Girard, 1852) in competitive settings - Aquac. Res. 36: 537-545.

Mazlum Y., Fatih M., Eversole, A. 2007 - Morphometric relationship of length weight and chelea length-width of eastern white river crayfish (Procambarus actus actus, Girard, 1852), under culture conditions - J. Appl. Ichthyol. 23: 616-620.

Milosevic D., Talevski T. 2016 - Length-weight relationship of 11 fish species from three natural and two artificial lakes in the former Yugoslav Republic of Macedonia (Fyrom) Acta Zool. Bulg. 68: 391-394.

Nakata K., Goshima S. 2003 - Competition for shelter of preferred sizes between the native crayfish species Cambaroides japonicus and the alien crayfish species
Pacifastacus leniusculus in Japan in relation to prior residence, sex difference, and body size - J. Crustac. Biol. 23: 897-907.

Patoka J., Blaha M., Kouba, A. 2015a - Cherax (Astaconephrops) gherardii, a new crayfish (Decapoda: Parastacidae) from West Papua, Indonesia - Zootaxa 3964: 526-536.

Patoka J., Blaha M., Kouba A. 2015b - Cherax (cherax) subterigneus, a new crayfish (Decapoda: Parastacidae) from West Papua, Indonesia - J. Crustac. Biol. 35: 830-838.

Pauly D. 1993 - Editorial. Fishbyte section - Naga, ICLARM Quarterly 16: 26-27.

Ricker W.E. 1975 - Computation and interpretation of biological statistics of fish populations - Bull. Fish. Res. Board Can. 191: 1-382.

Romaire R.P., Forester J.S., Avault J.W.Jr. 1977 Length-weight relationships of two commercially important crayfishes of the genus Procambarus - Freshw. Crayfish 3: 463-470.

Simon T.P., Stewart C.R. 2014 - Growth, length-weight relationships, and condition associated with gender and sexual stage in the invasive northern crayfish, Orconectes virilis Hagen, 1870 (Decapoda, Cambaridae - Proc. Indiana Acad. Sci. 123: 1-8.

Stein R.A. 1976 - Sexual dimorphism in crayfish chelae: functional significance linked to reproductive activities Can. J. Zool. 54: 220-227.

Streissl F., Hodl W. 2002 - Growth, morphometrics, size at maturity, sexual dimorphism and condition index of Austropotamobius torrentium Schrank - Hydrobiologia 477: 201-208.

Vorburger C., Ribi G. 1999 - Pacifastacus leniusculus and Austropotamobius torrentium prefer different substrates - Freshw. Crayfish 10: 696-704.

Wang Q., Yang W., Zhou G., Zhu Y., San H. 2011 Length-weight and chelae length-width relationships of the crayfish Procambarus clarkii under culture conditions - J. Freshw. Ecol. 26: 287-294.

Wetzel J.E. 2002 - Form alternation of adult female crayfishes of the genus Orconectes (Decapoda: Cambaridae) Am. Midl. Nat. 147: 326-337.

Weya J.M., Rumbiak N.S., Hariyanto S., Irawan B., Soegianto, A. 2017 - Length-weight relationship and condition factor of crayfish from South Sorong and Jayawijaya, Papua, Indonesia - Croat. J. Fish. 75: 18-24.

Zar J.H. 1999 - Biostatistical analysis. 4th ed. - Englewood Cliffs, Prentice-Hall. 